Review article

\title{
Severe Respiratory Complications in Obese Patients with SARS-CoV-2 Virus Infection: Characteristics and Oxygen Treatment
}

\author{
Vesna Marjanović ${ }^{1,2}$ \\ ${ }^{1}$ University of Niš, Faculty of Medicine, Nišs, Serbia \\ ${ }^{2}$ Clinic for Anesthesia and Intensive Therapy, Clinical Centre Niš, Niš, Serbia
}

SUMMARY

Considerable share of patients admitted to the intensive care unit, during the current Covid-19 pandemic, are obese. Obesity is associated with chronic low-grade inflammation, higher endothelial injury, higher levels of angiotensinogen II and increased expression of angiotensin-converting enzyme 2 receptors in the adipose tissue. These alterations along with accompanying comorbidities make the obese patients susceptible for the development of severe respiratory complications, including acute respiratory distress syndrome (ARDS) during SARS-CoV-2 infection. The choice of optimal mode of oxygen delivery rests on both a prior patient's functional status and the progress and severity of Covid-19 in obese patients. Non-invasive ventilation and high-flow nasal cannula, prone position and hyperbaric oxygen therapy are effective in obese patients with mild or moderate ARDS. If mechanical ventilation is unavoidable, lung protective ventilation mode with lower tidal volume and optimal positive end-expiratory pressure is crucial for treatment of SARS-CoV-2-induced ARDS. Extracorporeal membrane oxygenation is reserved only for patients with inadequate response to previous oxygen therapy. Optimal knowledge of physiological changes in obesity and timely treatment with adequate oxygen therapy could improve clinical outcome of these sensitive patient subgroup.

Key words: Covid-19, obesity, ARDS, oxygen therapy, respiratory support

Corresponding author:

Vesna Marjanović

e-mail: drvesnamarjanovic@gmail.com 


\section{INTRODUCTION}

Large share of the total number of patients admitted to the intensive care unit (ICU), during the current Covid-19 pandemic, are obese. Although the clinical picture of Covid-19 disease may vary from mild to severe forms, obese patients are at higher risk for the development of severe complications, including the acute respiratory distress syndrome (ARDS). In the US health care system, the percentage of obese hospitalized patients with Covid-19 was $41.7 \%$ (1), while $47.5 \%$ of those admitted to the ICU were obese with predominant $\mathrm{BMI} \geq 30 \mathrm{~kg} / \mathrm{m}^{2}(2,3)$. An altered response to SARS-CoV-2 infection is the result of the physiological changes in obesity and the accompanying respiratory, cardiovascular and renal comorbidities and coagulation system disturbances (4 - 6). This sensitive population required more invasive mechanical ventilation (IMV) in nearly $90 \%$ (2) and had a mortality rate of $62 \%$ compared to $36 \%$ recorded in lean patients (3). Mortality from Covid-19 in obese patients without comorbidities was 3-fold higher comparing to lean patients and reached up to 6-fold increase when obesity was associated with comorbidities (7).

The current treatment of Covid-19 disease is limited to the supportive care. However, in obese patients, traditional supportive care often fails, necessitating IMV. Once on the ventilator, Covid-19 patients are difficult to wean and the risk of mortality rises sharply. For the reasons given above, authors will discuss the mechanisms responsible for susceptibility to more severe disease development in obese patients. More importantly, the focus of this review will be on various approaches to oxygen delivery in SARS-CoV-2 virus-induced lung injury and ARDS with an emphasis on non-invasive mode of oxygen therapy in obese patients.

\section{PATHOPHYSIOLOGICAL CHANGES AND THE MOST COMMON COMORBIDITIES IN OBESE PATIENTS WITH COVID-19 INFECTION}

Obese patients are already at high risk of severe complications of Covid-19 infection due to their coherence with physiological changes such as chronic low-grade inflammation, higher endothelial injury, increased angiotensin-converting enzyme 2
(ACE-2) receptors concentration, and the higher activity of the renin-angiotensin-aldosterone system (RAAS).

The state of chronic low-grade inflammatory condition in obesity is characterized by increased circulating neutrophil levels (8), increased blood levels of adipokines and cytokines such as $\alpha$-interferon, TNF- $\alpha$, IL-1 $\beta$, IL-8 and IL-6 (9 - 11). Persistence of chronic low-grade inflammation impairs the immune-response (11) and influences the inflammation in the lung parenchyma and bronchi (12), with a consequent increase of susceptibility to infection or bacteremia in obese patients (13). The injury of endothelial microvasculature is a major contributor to increased permeability and development of pulmonary edema during acute lung injury and ARDS in this population. It is often a result of inadequate production of vasoactive agents and activation of innate immune cells (14 - 16). A combination of vasoconstriction and higher vascular inflammation with underlying atherosclerosis and a higher activity of platelets and adhesiveness of leukocytes leads to impairment of hemostasis and thrombosis in obese organisms (17). Angiotensinconverting enzyme 2 receptor on the cell surface is crucial for the penetration of SARS-CoV-2 virus into the human cells. There is a broad distribution of ACE-2 receptor expression on human tissues and organs including the gastrointestinal tract, lung, heart and kidney (18). The adipose tissue also strongly expresses ACE-2 receptor, making these cells an important viral reservoir (19). Adipocytes are also highly active in the production of circulating angiotensinogen and angiotensin II $(20,21)$. This may partially explain a higher activity of the reninangiotensin-aldosterone system activity in obese patients (22). The implications of these finding in Covid-19 infection are unfavorable, especially having in mind the data concerning a positive correlation between a higher level of angiotensin II and the severity of lung injury. More precisely, the higher level of angiotensin II induces pulmonary vasoconstriction and disrupts the ventilation/perfusion mismatch, leading to hypoxemia and promoting acute lung injury (18). The abovementioned mechanism is not unique for a high predisposition of the obese patients to develop severe lung injury and exacerbation of Covid-19 infection $(23,24)$.

The list of comorbidities and physiological changes caused by obesity is long and is beyond the 
scope of this review. Further discussion will be focused only to factors considered significant for the development of severe clinical picture during SARS CoV-2 infection.

Due to mechanical effects, obese individuals often develop atelectasis. They also have decreased total lung capacity, lower functional residual capacity and vital capacity. Their airway resistance and closure are increased, respiratory muscle strength is lower and ventilation/perfusion mismatch is more pronounced than in lean individuals (25). Their ventilation of the lung base is impaired and cause decreased oxygen saturation of blood (26). The changes in respiratory physiology might contribute to more frequent admission to ICU and the need for assisted ventilation in SARS-CoV-2 related pneumonia, compared to normal weight population, even in younger age patients (27). These factors could also increase the sensitivity for the development of ventilator-associated lung injury during IMV. Coronary heart disease and hypertension are also more commonly present in obese population, especially in cases with higher level of low-density lipoprotein cholesterol and triglycerides with diabetes mellitus type II, metabolic syndrome and "visceral" obesity (28). Functional changes of nephrons that include glomerular and podocyte dysfunction are often the cause of chronic kidney disease in obese patients. It was found that the central adipose tissue could decrease estimated glomerular filtration rate and effective renal plasma flow with the consequent subnephrotic proteinuria (20). Obese patients are at higher risk of developing venous thromboembolism due to hypercoagulability (29). Obesity-related hypercoagulability is multifactorial. It is associated with higher level of adipocytokines, hyperactivity of coagulation factors, decreased fibrinolysis, increased level of angiotensin II, endothelial dysfunction, venous stasis and impaired venous return $(30,31)$. Therefore, obese patients with Covid-19 have increased hypercoagulability and thrombosis as a result of both effects, obesity and viral infection.

\section{OXYGEN THERAPY IN OBESE COVID-19 PATIENTS}

Acute respiratory failure due to prolonged hypoxemia is the major manifestation in severe Covid-19 disease with the poor outcome in these patients (32). The development of respiratory complications in obese patients is characterized by the deterioration of pulmonary clinical picture and low partial pressure of arterial oxygen $\left(\mathrm{PaO}_{2}\right)$ and oxygen saturation $\left(\mathrm{SaO}_{2}\right)$ on admission to the levels requiring higher inspiratory fraction of oxygen and prolonged oxygen delivery in order to improve oxygenation (33). Thresholds for titrating ventilation settings in obese patients with ARDS are: $\mathrm{SaO}_{2}$ between $88-94 \%, \mathrm{PaO}_{2}$ between $55-80 \mathrm{~mm} \mathrm{Hg}$ and carbon dioxide levels leading to drop of $\mathrm{pH}>7.25$ (34). Other authors have suggested different criteria in Covid-19 positive patients, such as: respiratory rate $\geq 30$ breaths per minute, $\mathrm{SaO}_{2} \leq 93 \%$, partial pressure of arterial oxygen to fraction of inspired oxygen $\left(\mathrm{PaO}_{2} / \mathrm{FiO}_{2}\right)$ ratio $<300 \mathrm{~mm} \mathrm{Hg}$, and increase in lung infiltrates > $50 \%$ within $24-48 \mathrm{~h}$ (35). Whatever criterion is chosen, rational and effective respiratory support is crucial in the management of Covid-19 patients, especially for obese patients. So far, oxygenation in patients with Covid-19 lung disease has been done mostly with non-invasive respiratory support as noninvasive ventilation (NIV), (in $44 \%$ of patients in one large patient series), and high-flow nasal cannula (HFNC) (in 11\% of cases in the same cohort), as well as with invasive mechanical ventilation (IMV) (in 47\% cases), and only in few cases ARDS was treated with extracorporeal membrane oxygenation (ECMO) (36). The use of NIV is optimal for hemodynamically stable patients with mild to moderate ARDS matching levels of $\mathrm{PaO}_{2} / \mathrm{FIO}_{2}>200 \mathrm{~mm} \mathrm{Hg}$ (37). In severely hypoxemic patients with ARDS and $\mathrm{PaO}_{2} / \mathrm{FIO}_{2}<200 \mathrm{~mm}$ $\mathrm{Hg}$, IMV should be a therapeutic option (38).

Lung deterioration in early phase during Covid-19 infection could be treated using NIV and HFNC, with or without placing a patient in the prone position (38 - 40), or using hyperbaric oxygen therapy (41). These modalities could delay intubation and IMV (42). Non-invasive ventilation and HFNC were used in about one-third and two-thirds of critically ill patients with Covid-19 in China, respectively (39, 43, 44). The use of NIV and HFNC may decrease the need for tracheal intubation without the influence on mortality $(42,44)$, although some authors have reported increased mortality when HNFC was used in unselected patients (45). Another contradictory report has found that prolonged use of NIV or HFNC in Covid-19 patients is associated with higher risk of emergency intubation and prolonged desaturation after intubation (46).

The NIV method of oxygenation with continuous positive airway pressure (CPAP) could efficiently recruit alveolar units, improve hypoxemia 
and reduce the work of breathing. The clinical goal of NIV method it to maintain at least minimal respiratory capacity. These benefits are possible if only careful titration and close monitoring of obese patients are performed (47). In case of hypercapnia, NIV with the application of higher positive end-expiratory pressure (PEEP) should be used for prolonged time (48). In case of NIV treatment associated with unsuccessful CPAP and PEEP above $10 \mathrm{~cm} \mathrm{H}_{2} \mathrm{O}$, the risk of rapid clinical status worsening within a few hours is high and patients may require $\operatorname{IMV}(49,50)$. Unsuccessful NIV treatment could be expected in comatose patients with sufficient breathing and in anxious patients with increased respiratory drive because of hypercapnic encephalopathy. For these conditions, NIV is considered inappropriate (37). Tolerance of NIV could be achieved with remifentanil that could make a balance between the reduction of respiratory drive and maintenance of breathing capacity (51).

The application of HFNC for oxygen therapy in severe and critically ill Covid-19 patients is summarized in the following experiences. Firstly, it is important to provide the proper size of nasal catheter and maintain the patency of the upper respiratory airway. Secondly, an initial flow of humidified and warmed oxygen $(60 \mathrm{~L} / \mathrm{min})$ with an adjustable $\mathrm{FiO}_{2}$ should be given immediately to patients with obvious respiratory distress or weak cough ability; otherwise, low-level support should be given first and the amount should be successively and gradually increased. Thirdly, $\mathrm{SpO}_{2}$ should be kept above 95\% when using HFNC in order to avoid hypoxia or hypoxemia in patients without chronic pulmonary disease. Finally, patients should wear a surgical mask during HFNC treatment in order to reduce the risk of virus transmission through droplets or aerosols (52). Failure of HFNC could be avoided with proper selection of patients, i.e. who do not have extreme hyperventilation, with timely application and with improvement of compliance (50). It should be noted that older patients are vulnerable if HFNC fails (53). Until further data are available, HFNC and NIV alone or with prone position should be reserved for patients with mild or moderate ARDS (54). Minimal data exist to confirm or refute safety concerns regarding the risk of aerosol generation by these devices. Epidemiological sources suggest that NIV was linked with nosocomial transmission of SARS (55) and with generation of the aerosols, which was not in concordance with other report (56). In spite of the lack of evidence, the use of side room or negative pressure rooms, pre-emptive change of mask and circuit with a viral filter in combination with personal protective equipment should minimize the risk for aerosol generation (57). Also, the use of helmet during the application of CPAP could prevent generations of aerosols (47).

Prone positioning should be applied as an early therapeutic option, given its association with improved oxygen saturation and reduced mortality in Covid-19-related ARDS. Although outcome data on prone positioning in Covid-19 are currently lacking, (proning was used in $12 \%$ of patients in one ICU study from Wuhan) (39) the tendency for SARS-CoV2 to affect the peripheral and dorsal areas of the lungs provides the ideal conditions for a positive oxygenation response to prone positioning. In short, while median $\mathrm{SpO}_{2}$ at triage was $80 \%$, after the application of supplemental oxygen with room air, it raised to $84 \%$, and after 5 minutes of proning, $\mathrm{SpO}_{2}$ improved to $94 \%$. However, $24 \%$ of patients failed to improve after proning, maintained poor oxygen saturation, requiring endotracheal intubation within 24 hours since the arrival to the emergency department (32). These patients showed intolerance to prone positioning due to anxiety or their impossibility to change position (58).

Hyperbaric oxygen therapy (HBOT) represents another feasible option for the prevention of IMV in Covid-19 patients with tachypnea and low oxygen saturation, especially if high $\mathrm{FiO}_{2}$ oxygenation is applied. HBOT may reverse hypoxia and pulmonary inflammation with its anti-inflammatory and potentially viricidal properties, although the exact mechanism of action is unclear. A single HBOT treatment could cause the prompt resolution of labored breathing with the rise in $\mathrm{SaO}_{2}$ values and improved symptoms in Covid-19 patients. A decrease in oxygen requirement below $\mathrm{FiO}_{2}$ of $50 \%$ took between one and six HBOT sessions, with an average of five HBOT treatments per patient (41).

Although the majority patients with Covid-19related ARDS received NIV, the strategy of early intubation and IMV showed a better outcome in these patients than NIV. After 2 weeks of receiving IMV, $22 \%$ of patients were extubated, $47 \%$ underwent IMV and $31 \%$ died (50). There are contradictory results where early intubation and IMV could increase the mortality and prolonged extubation time of these patients (42). Until now, there is no precise consensus and the final decision is according to personal 
assessment of the anesthesiologist. Clinical experience with in SARS-CoV-2 infection has shown that emergency tracheal intubation was more often necessary in male patients, aged 65 years or more, and those hypoxemic with $\mathrm{SaO}_{2}<90 \%$ (59). When hypoxemia is severe, with $\mathrm{PaO}_{2} / \mathrm{FIO}_{2} \leq 200 \mathrm{mmHg}$, intubation and IMV is the treatment of choice. The main goal of IMV in ARDS induced by SARS-CoV-2 is the avoidance of ventilator-induced lung injury, while facilitating gas exchange via lung-protective ventilation (60). Lung-protective ventilation might compensate diminished functional residual capacity in obese patients and improve oxygenation $(61,62)$. Lung-protective ventilation with low tidal volume $\mathrm{Vt}$ $\leq 6 \mathrm{ml} / \mathrm{kg}$, optimal PEEP $\left(>10 \mathrm{~cm} \mathrm{H} \mathrm{H}_{2} \mathrm{O}\right.$ ) and inspiratory airway pressure $\leq 30 \mathrm{cmH}_{2} \mathrm{O}$ has become a cornerstone of management in obese patients $(39,45$, 63). Another method of lung protective ventilation in obese patients with ARDS might be the use of higher tidal volume $(8 \mathrm{ml} / \mathrm{kg})$, although it is still unclear whether tidal volume should be based on estimated or ideal body weight (64). Also, individualized PEEP titration to mean values of $18 \mathrm{~cm} \mathrm{H}{ }_{2} \mathrm{O}$, with electrical impedance tomography, could optimize end-expiratory lung volume (65). Higher inspiratory airway pressure could promote ventilator-induced lung injury and increase the risk of barotrauma. Therefore, more research is needed for better implementation of lung-protective ventilation in these patients. In the selected cases, recruitment manoeuvres and prone positioning may be required to counteract the onset of atelectasis in the dependent region of the lungs, but their use remain controversial $(61,66)$. In cases of severe ARDS with a $\mathrm{PaO}_{2} / \mathrm{FIO}_{2}<150 \mathrm{~mm} \mathrm{Hg}$, prone positioning of the patients should be consistently done in at least $16 \mathrm{~h}$ intervals. From the aspect of ventilation, these patients need high PEEP and responded favourably to recruitment ma-noeuvres with the application of inhalational nitro-oxide and muscle relaxants (67). Extracorporeal membrane oxygenation is reserved only for patients with the most severe ARDS, with some evidence that it might improve survival. This approach is considered as a rescue therapy if lung protective ventilation combined with lung recruitment manoeuvre, prone positioning and high-frequency oscillation ventilation shows no improvement $(68,69)$.

\section{CONCLUSION}

Obesity induce chronic low-grade inflammation and endothelial injury, increased expression of ACE2 receptors in adipose tissue and higher level of angiotensinogen II. Along with accompanying comorbidities, these factors make the obese patients vulnerable for the development of Covid-19-related ARDS and unfavourable outcome. The choice of oxygen therapy in obese patients should be based not only on the progress and severity of Covid-19, but also on their prior functional status. Non-invasive respiratory support alone or with prone positioning and hyperbaric oxygen therapy are recommended for cases with mild or moderate ARDS and for preventing or delaying intubation and invasive mechanical ventilation of Covid-19- related ARDS. Covid-19related ARDS requires increased attention and the use of lung protective mechanical ventilation, with utilization of lower tidal volume and optimal positive end-expiratory pressure. Transition from mechanical ventilation to extracorporeal membrane oxygenation is reserved for patients with resistant ARDS. Optimal knowledge of physiology and comorbidities of obese patients with timely and adequately non-invasive respiratory support could improve the clinical outcome of these high-risk patients with SARS-CoV-2 induced ARDS. 


\section{References}

1. Richardson S, Hirsch JS, Narasimhan M, et al. Presenting Characteristics, Comorbidities, and Outcomes Among 5700 Patients Hospitalized With COVID-19 in the New York City Area. JAMA 2020:e206775.

\section{https://doi.org/10.1001/jama.2020.6775}

2. Simonnet A, Chetboun M, Poissy J, et al. High prevalence of obesity in severe acute respiratory syndrome coronavirus-2 (SAR S-C oV-2) requiring invasive mechanical ventilation. 2020; 28(7):11951199.

\section{https://doi.org/10.1002/oby.23006}

3. Bhatraju PK, Ghassemieh BJ, Nichols M, et al. Covid-19 in critically ill patients in the Seattle regionCase Series. N Engl J Med 2020;382(21):2012-2022. https://doi.org/10.1056/NEJMoa2004500

4. Lavie CJ, Laddu D, Arena R, et al. Healthy weight and obesity prevention: JACC health promotion series. J Am Coll Cardiol 2018;72(13):1506-1531. https://doi.org/10.1016/j.jacc.2018.08.1037

5. Elagizi A, Kachur S, Lavie CJ. An overview and update on obesity and the obesity paradox in cardiovascular diseases. Prog Cardiovasc Dis 2018;61(2):142-150.

https://doi.org/10.1016/j.pcad.2018.07.003

6. Fang L, Karakiulakis G, Roth M. Are patients with hypertension and diabetes mellitus at increased risk for COVID-19 infection? Lancet Respir Med 2020;8(4):E21.

https://doi.org/10.1016/S2213-2600(20)30116-8

7. Gao F, Zheng KI, Wang XB, et al. Obesity is a risk factor for greater COVID-19 severity. Diabetes Care 2020;43(7):e72-e74. https://doi.org/10.2337/dc20-0682
8. Kim JA, Park HS. White blood cell count and abdominal fat distribution in female obese adolescents. Metabolism 2008;57(10):1375-9. https://doi.org/10.1016/j.metabol.2008.05.005

9. Ramos EJ, Xu Y, Romanova I, et al. Is obesity an inflammatory disease? Surgery 2003;134(2):329-35. https://doi.org/10.1067/msy.2003.267

10. Peters MC, McGrath KW, Hawkins GA, et al. Plasma interleukin-6 concentrations, metabolic dysfunction, and asthma severity: a cross-sectional analysis of two cohorts. Lancet Respir Med 2016;4(7):574-84.

https://doi.org/10.1016/S2213-2600(16)30048-0

11. Huttunen R, Syrjänen J. Obesity and the risk and outcome of infection. Int $\mathrm{J}$ Obes (Lond) 2013;37(3):333-40.

https://doi.org/10.1038/ijo.2012.62

12. Zhang $\mathrm{X}$, Zheng J, Zhang $\mathrm{L}$, et al. Systemic inflammation mediates the detrimental effects of obesity on asthma control. Allergy Asthma Proc 2017.

https://doi.org/10.2500/aap.2017.38.4096

13. Matarese G, Moschos S, Mantzoros CS. Leptin in immunology. J Immunol 2005;174(6):3137-42. https://doi.org/10.4049/jimmunol.174.6.3137

14. Pontiroli AE, Frige F, Paganelli M, Folli F. In morbid obesity, metabolic abnormalities and adhesion molecules correlate with visceral fat, not with subcutaneous fat: effect of weight loss through surgery. Obes Surg 2009;19(6):745-50. https://doi.org/10.1007/s11695-008-9626-4

15. Shah D, Romero F, Duong M, et al. Obesityinduced adipokine imbalance impairs mouse 
pulmonary vascular endothelial function and primes the lung for injury. Sci Rep 2015;5:11362. https://doi.org/10.1038/srep11362

16. Jain M, Budinger GR, Lo A, et al. Leptin promotes fibroproliferative acute respiratory distresssyndrome by inhibiting peroxisome proliferator-activated receptor-gamma. Am J Respir Crit CareMed 2011;183(11):1490-8. https://doi.org/10.1164/rccm.201009-1409OC

17. Kwaifa IK, Bahari $\mathrm{H}$, Yong YK, Noor SM. Endothelial dysfunction in obesity-induced inflammation: molecular mechanisms and clinical implications. Biomolecules 2020;10(2):291. https://doi.org/10.3390/biom10020291

18. Kuba K, Imai $Y$, Rao $S$, et al. A crucial role of angiotensin converting enzyme 2 (ACE2) in SARS coronavirus-induced lung injury. Nat Med 2005;11(8):875-9.

https://doi.org/10.1038/nm1267

19. Jia $X$, Yin $C$, Lu S, et al. Two things about COVID19 might need attention. Preprints 2020 https://doi.org/10.20944/preprints202002.0315.v1

20. Lakkis JI, Weir MR. Obesity and kidney disease. Prog Cardiovasc Dis 2018;61(2):157-67. https://doi.org/10.1016/j.pcad.2018.07.005

21. Bornstein SR, Dalan R, Hopkins D, et al. Endocrine and metabolic link to coronavirus infection. Nat Rev Endocrinol 2020;16(6):297-8. https://doi.org/10.1038/s41574-020-0353-9

22. Cabandugama PK, Gardner MJ, Sowers JR. The renin angiotensin aldosterone system in obesity and hypertension: roles in the cardiorenal metabolic syndrome. Med Clin North Am 2017;101(1):129-37.

https://doi.org/10.1016/j.mcna.2016.08.009

23. Henry BM, Vikse J. Clinical characteristics of Covid-19 in China. N Engl J Med 2020;382(19):1860-1.

https://doi.org/10.1056/NEJMc2005203

24. Saiki A, Ohira M, Endo K. Circulating angiotensin II is associated with body fat accumulation and insulin resistance in obese subjects with type 2 diabetes mellitus. Metabolism 2009;58(5):708-13. https://doi.org/10.1016/j.metabol.2009.01.013

25. Murugan AT, Sharma G. Obesity and respiratory diseases. Chron Respir Dis 2008;5:233-42. https://doi.org/10.1177/1479972308096978

26. Dixon AE, Peters U. The effect of obesity on lung function. Expert Rev Respir Med 2018;12(9):75567. doi: 10.1080/17476348.2018.1506331.Busetto L, Bettini S, Fabris R, et al. Obesity and COVID-19: An Italian Snapshot

27. (Silver Spring) 202028(9):1600-5. https://doi.org/10.1002/oby.22918

28. Jin J. JAMA patient page. Obesity and the heart. JAMA 2013;310(19):2113. https://doi.org/10.1001/jama.2013.281901

29. Darvall KA, SamRC, Silverman SH, et al. Obesity and thrombosis. Eur J Vasc Endovasc Surg 2007;33(2):223-33. https://doi.org/10.1016/j.ejvs.2006.10.006

30. Campello E, Zabeo E, Radu CM, et al. Hypercoagulability in overweight and obese subjects who are asymptomatic for thrombotic events. Thromb Haemost 2015;113(1):85-96. https://doi.org/10.1160/TH14-02-0156

31. Samad F, Ruf W. Inflammation, obesity, and thrombosis. Blood 2013;122(20):3415-22. https://doi.org/10.1182/blood-2013-05-427708

32. Caputo ND, Strayer RJ, Levitan R. Early SelfProning in Awake, Non-intubated Patients in the Emergency Department: A Single ED's Experience During the COVID-19 Pandemic. Acad Emerg Med 2020;27(5):375-8. doi: 10.1111/acem.13994. https://doi.org/10.1111/acem.13994

33. Moriconi D, Masi S, Rebelos E, et al. Obesity prolongs the hospital stay in patients affected by COVID-19, and may impact on SARS-COV-2 shedding. Obes Res Clin Pract 2020;14(3):205-209. https://doi.org/10.1016/j.orcp.2020.05.009

34. Ball L, Pelosi P. How I ventilate an obese patient. 
Crit Care 2019;23(1):176.

https://doi.org/10.1186/s13054-019-2466-x

35. WHO-China Joint Mission. Report of the WHOChina Joint Mission on Coronavirus Disease 2019 (COVID-19). Feb 28,2020.

https://www.who.int/docs/defaultsource/coronaviruse/who-china-joint-mission-oncovid-19-final-report.pdf (accessed March 7, 2020)

36. Wang D, Hu B, Hu C, et al. Clinical Characteristics of 138 Hospitalized Patients With 2019 Novel Coronavirus-Infected Pneumonia in Wuhan, China. JAMA 2020;323(11):1061-9. https://doi.org/10.1001/jama.2020.1585

37. Nava S, Hill N. Non-invasive ventilation in acute respiratory failure. Lancet 2009;374(9685):250-9. https://doi.org/10.1016/S0140-6736(09)60496-7

38. Ranieri VM, Rubenfeld GD, Thompson BT, et al. Acute respiratory distress syndrome: the Berlin Definition. JAMA 2012;307(23):2526-33. https://doi.org/10.1001/jama.2012.5669

39. Yang $\mathrm{X}, \mathrm{Yu} \mathrm{Y}, \mathrm{Xu} \mathrm{J}$, et al. Clinical course and outcomes of critically ill patients with SARS-CoV-2 pneumonia in Wuhan, China: a single centered, retrospective, observational study. Lancet Respir Med 2020;8(5):475-81.

https://doi.org/10.1016/S2213-2600(20)30079-5

40. Despres C, Brunin Y, Berthier F, et al. Prone positioning combined with high-flow nasal or conventional oxygen therapy in severe Covid-19 patients. Crit Care 2020;24(1):256.

https://doi.org/10.1186/s13054-020-03001-6

41. Thibodeaux K, Speyrer M, Raza A, et al. Hyperbaric oxygen therapy in preventing mechanical ventilation in COVID-19 patients: a retrospective case series. J Wound Care 2020;29(Sup5a):S4-S8.

https://doi.org/10.12968/jowc.2020.29.Sup5a.S4

42. Raoof S, Nava S, Carpati C, Hill NS. High Flow, Non-invasive ventilation and Awake (nonintubation) Proning in Covid-19 Patients with Respiratory Failure". Chest 2020 Jul 15;S00123692(20)31910-3.

https://doi.org/10.1016/j.chest.2020.07.013
43. Huang C, Wang Y, Li X, et al. Clinical features of patients infected with 2019 novel coronavirus in Wuhan, China. Lancet 2020;395(10223):497-506. https://doi.org/10.1016/S0140-6736(20)30183-5

44. Zhang Y, Fang C, Dong BR, et al. Oxygen therapy for pneumonia in adults. Cochrane Database Syst Rev 2012;(3):CD006607. https://doi.org/10.1002/14651858.CD006607.pub4

45. Kang BJ, Koh Y, Lim CM, et al. Failure of highflow nasal cannula therapy may delay intubation and increase mortality. Intensive Care Med 2015;41(4):623-32. https://doi.org/10.1007/s00134-015-3693-5

46. Brewster DJ, Chrimes N, Do TB, et al. Consensus statement: Safe Airway Society principles of airway management and tracheal intubation specific to the COVID-19 adult patient group. Med J Aust 2020;212(10):472-81. https://doi.org/10.5694/mja2.50598

47. Radovanovic D, Rizzi M, Pini S, et al. Helmet CPAP to Treat Acute Hypoxemic Respiratory

Failure in Patients with COVID-19: A Management Strategy Proposal. J Clin Med 2020;9(4):1191.

https://doi.org/10.3390/jcm9041191

48. Gursel G, Aydogdu M, Gulbas G, et al. The influence of severe obesity on non-invasive ventilation (NIV) strategies and responses in patients with acute hypercapnic respiratory failure attacks in the ICU. Minerva Anestesiol 2011;77:17-25. PMID: 21273965.

49. Nightingale R, Nwosu N, Kutubudin F, et al. Is continuous positive airway pressure (CPAP) a new standard of care for type 1 respiratory failure in COVID-19 patients? A retrospective observational study of a dedicated COVID-19 CPAP service. BMJ Open Respir Res 2020;7(1):e000639.

https://doi.org/10.1136/bmjresp-2020-000639

50. Barrasa H, Rello J, Tejada S, et al. SARS-CoV-2 in Spanish Intensive Care Units: Early experience with 15-day survival in Vitoria. Anaesth Crit Care Pain Med 2020; 39(5):553-61 S2352-5568(20)30064-3. https://doi.org/10.1016/j.accpm.2020.04.001 
51. Rocco M, Conti G, Alessandri E, et al. Rescue treatment for non invasive ventilation failure due to interface intolerance with remifentanil analgosedation: a pilot study. Intensive Care Med 2010;36(12):2060-5. https://doi.org/10.1007/s00134-010-2026-y

52. He G, Han Y, Fang Q, et al. Clinical experience of high-flow nasal cannula oxygen therapy in severe COVID-19 patients. Zhejiang Da Xue Xue Bao Yi Xue Ban 2020;49(2):232-9. doi: 10.3785/j.issn.10089292.2020.03.13.

53. Yao $\mathrm{W}$, Wang $\mathrm{T}$, Jiang $\mathrm{B}$, et al. Emergency tracheal intubation in 202 patients with COVID-19 in Wuhan, China: lessons learnt and international expert recommendations. Br J Anaesth 2020; 125(1):E28-31 S0007-0912(20)30203-8. https://doi.org/10.1016/j.bja.2020.03.026

54. Winck JC, Ambrosino N. COVID-19 pandemic and noninvasive respiratory management: Every Goliath needs a David. An evidence based evaluation of problems. Pulmonology 2020; 26(4):213-20S2531-0437(20)30093-3. https://doi.org/10.1016/j.pulmoe.2020.04.013

55. Tran K, Cimon K, Severn M, et al. Aerosol generating procedures and risk of transmission of acute respiratory infections to healthcare workers: a systematic review. PLoS One 2012;7:e35797.34. https://doi.org/10.1371/journal.pone.0035797

56. Simonds AK, Hanak A, Chatwin M, et al. Evaluation of droplet dispersion during noninvasive ventilation, oxygen therapy, nebuliser treatment and chest physiotherapy in clinical practice: implications for management of pandemic influenza and other airborne infections. Health Technol Assess 2010;14(46):131-72. https://doi.org/10.3310/hta14460-02

57. Baker JG, Sovani M. Case for continuing community NIV and CPAP during the COVID-19 epidemic. Thorax 2020;75(5):368.

https://doi.org/10.1136/thoraxjnl-2020-214913

58. Di Silvio B, Young M, Gordon A, et al. Complications and outcomes of acute respiratory distress syndrome. Crit Care Nurs Q 2019;42(4):34961.
https://doi.org/10.1097/CNQ.0000000000000275

59. Wang J, Lu F, Zhou M, et al. Tracheal intubation in patients with severe and critical COVID-19: analysis of 18 cases. Nan Fang Yi Ke Da Xue Xue Bao 2020;40(3):337-41. doi: 10.12122/j.issn.1673-4254.2020.03.07.

60. Matthay MA, Aldrich JM, Gotts JE. Treatment for severe acute respiratory distress syndrome from COVID-19. Lancet Respir Med 2020;8(5):433-4. https://doi.org/10.1016/S2213-2600(20)30127-2

61. Bonatti G, Robba C, Ball L, et al. Controversies when using mechanical ventilation in obese patients with and without acute distress respiratory syndrome. Expert Rev Respir Med 2019;13(5):471-9.

https://doi.org/10.1080/17476348.2019.1599285

62. Lewandowski K. The Critically Ill Obese Patient: Too Big to Fail? Anasthesiol Intensivmed Notfallmed Schmerzther 2019;54(4):256-66. https://doi.org/10.1055/a-0636-2735

63. Chen L, Brochard L. Lung volume assessment in acute respiratory distress syndrome. Curr Opin Crit Care 2015;21(3):259-64. https://doi.org/10.1097/MCC.0000000000000193

64. Kalra SS, Siuba M, Panitchote A, et al. Higher Class of Obesity Is Associated With Delivery of Higher Tidal Volumes in Subjects With ARDS. Respir Care 2020 Mar 24:respcare.07110. https://doi.org/10.4187/respcare.07110

65. Nestler C, Simon P, Petroff D, et al. Individualized positive end-expiratory pressure in obese patients during general anaesthesia: a randomized controlled clinical trial using electrical impedance tomography. Br J Anaesth 2017;119:1194-205. https://doi.org/10.1093/bja/aex192

66. Jong AD, Verzilli D, Jaber S. ARDS in Obese Patients: Specificities and Management. Critical Care 2019;23(1):74. https://doi.org/10.1186/s13054-019-2374-0

67. Aoyama H, Uchida K, Aoyama K, et al. Assessment of therapeutic interventions and lung protective ventilation in patients with moderate to 
severe acute respiratory distress syndrome: a systematic review and network meta-analysis. JAMA Netw Open 2019;2(7):e198116.

https://doi.org/10.1001/jamanetworkopen.2019.8116

68. Alshahrani MS, Sindi A, Alshamsi F, et al. Extracorporeal membrane oxygenation for severe Middle East respiratory syndrome coronavirus. Ann Intensive Care 2018;8(1):3. https://doi.org/10.1186/s13613-017-0350-x

69. Ramanathan K, Antognini D, Combes A, et al. Planning and provision of ECMO services for severe ARDS during the COVID-19 pandemic and other outbreaks of emerging infectious diseases. Lancet Respir Med 2020;8(5):518-26.

https://doi.org/10.1016/S2213-2600(20)30121-1 


\title{
Teške respiratorne komplikacije kod gojaznih bolesnika sa SARS-CoV-2 virusnom infekcijom: karakteristike i oksigenoterapija
}

\author{
Vesna Marjanovićc ${ }^{1,2}$ \\ ${ }^{1}$ Univerzitet u Nišu, Medicinski fakultet, Niš, Srbija \\ ${ }^{2}$ Klinika za anesteziju i intenzivnu terapiju, Klinički centar Niš, Niš, Srbija
}

\section{S A ŽETAK}

Značajan procenat bolesnika primljenih u Jedinicu intenzivne nege tokom pandemije Covid-19, bili su gojazni bolesnici. Gojaznost je povezana sa hroničnom inflamacijom niskog stepena, većim stepenom endotelnog oštećenja i nivoom angiotenzinogena II, kao i povećanom ekspresijom receptora za angiotenzin konvertujući enzim 2 u masnom tkivu. Ove promene udružene sa komorbiditetima, čine gojazne bolesnike podložnijim za razvoj teških respiratornih komplikacija, uključujući i akutni respiratorni distres sindrom (ARDS), tokom SARS-CoV-2 infekcije. Izbor optimalnog načina isporuke kiseonika kod gojaznih bolesnika zavisi od njihovog funkcionalnog statusa $\mathbf{i}$ uznapredovalosti Covid-19 infekcije. Neinvazivna ventilacija $\mathbf{i}$ visoki protok kiseonika putem nosne kanile, potrbušni položaj bolesnika i hiperbarični kiseonik, predstavljaju efikasne načine oksigenacije gojaznih bolesnika sa blažom ili umerenom formom ARDS. Ukoliko je mehanička ventilacija neophodna, primena protektivne ventilacije pluća sa manjim disajnim volumenom i optimalnim pozitivnim pritiskom na kraju ekspirijuma, od presudnog je značaja za lečenje SARS-CoV-2 uzrokovanog ARDS. Ekstrakorporalna membranska oksigenacija rezervisana je samo za bolesnike sa neadekvatnim odgovorom na prethodni mod ventilacije. Optimalno poznavanje patofizioloških promena gojaznosti i blagovremeno lečenje, uz adekvatnu primenu kiseonične terapije, može poboljšati klinički ishod ove osetljive grupe bolesnika.

Ključne reči: Covid-19, gojaznost, ARDS, oksigenoterapija, respiratorna potpora 